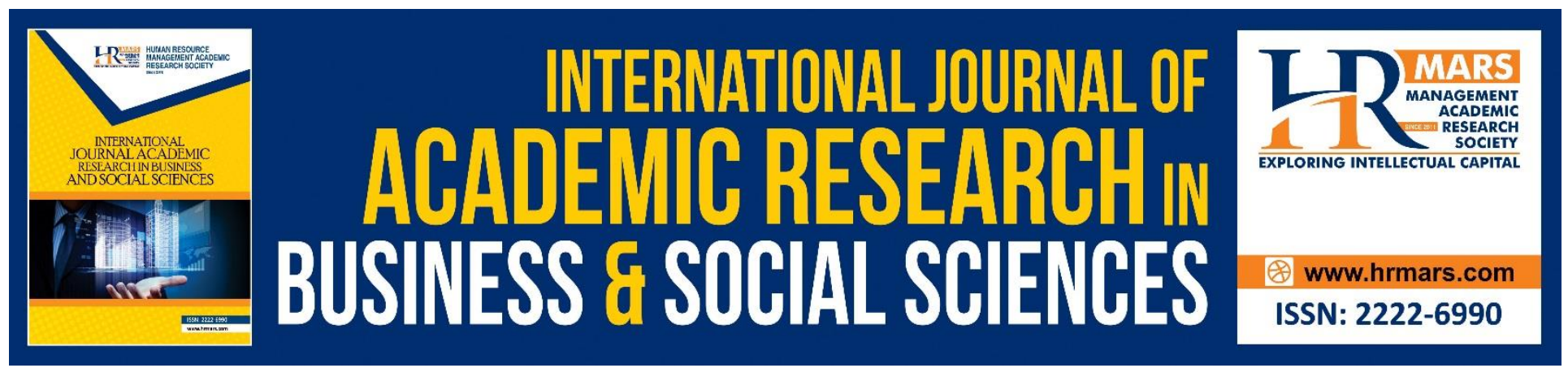

\title{
The Influence of Personal Factors on Professional Employees' Intention to Stay: Job Satisfaction as Mediator
}

\author{
Nurhazimah Kusnin and Roziah Mohd Rasdi
}

To Link this Article: http://dx.doi.org/10.6007/IJARBSS/v8-i10/4794

DOI: $10.6007 /$ IJARBSS/v8-i10/4794

Received: 18 Sept 2018, Revised: 28 Oct 2018, Accepted: 04 Nov 2018

Published Online: 10 Nov 2018

In-Text Citation: (Kusnin \& Rasdi, 2018)

To Cite this Article: Kusnin, N., \& Rasdi, R. M. (2018). The Influence of Personal Factors on Professional Employees' Intention to Stay: Job Satisfaction as Mediator. International Journal of Academic Research in Business and Social Sciences, 8(10), 989-1004.

\section{Copyright: (C) 2018 The Author(s)}

Published by Human Resource Management Academic Research Society (www.hrmars.com)

This article is published under the Creative Commons Attribution (CC BY 4.0) license. Anyone may reproduce, distribute, translate and create derivative works of this article (for both commercial and non-commercial purposes), subject to full attribution to the original publication and authors. The full terms of this license may be seen

at: $\underline{\text { http://creativecommons.org/licences/by/4.0/legalcode }}$

Vol. 8, No. 10, 2018, Pg. 989 - 1004

http://hrmars.com/index.php/pages/detail/IJARBSS

JOURNAL HOMEPAGE

Full Terms \& Conditions of access and use can be found at http://hrmars.com/index.php/pages/detail/publication-ethics 


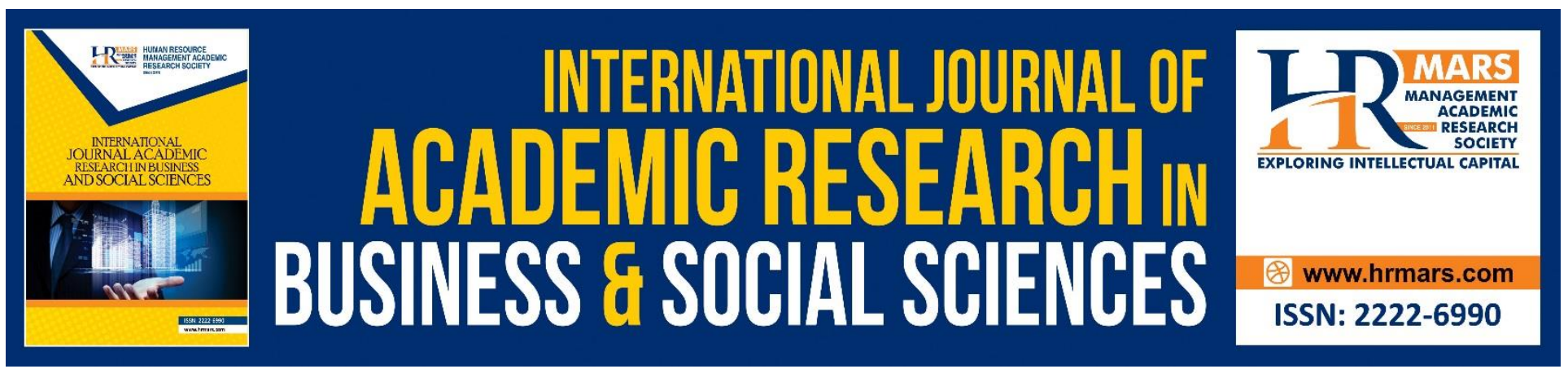

\title{
The Influence of Personal Factors on Professional Employees' Intention to Stay: Job Satisfaction as Mediator
}

\author{
Nurhazimah Kusnin and Roziah Mohd Rasdi \\ Faculty of Educational Studies, Universiti Putra Malaysia, 43400 Serdang, Selangor, MALAYSIA
}

\begin{abstract}
One of the most emerging issues in the field of Human Resource Development is how to effectively help professional employees to retain in organizations. Structural equation modelling (SEM-AMOS) was employed to examine factors influencing intention to stay among professionals and the mediation role of job satisfaction in the correlational relationships. Survey forms were collected from 457 professionals in Malaysia. The results revealed that personal-related factors (emotional intelligence and self-efficacy) have significant impact on professionals' intention to stay, and job satisfaction mediated the relationship between personal-related factors and intention to stay. The findings of this study are useful for HRD practitioners to develop the interventions to assist individuals and organizations towards successful self-development and sustainable organizations.
\end{abstract}

Keywords: Emotional Intelligence, Self-Efficacy, Job Satisfaction, Intention to Stay, Human Resource Development

\section{INTRODUCTION}

The changes in work nature based on the competitive global business environment has influenced employees' career development (Gubler, Arnold, and Coombs, 2013). Employees are essential assets in the organization regardless of what nature the business were, considering the non-imitated characteristics of this competitive advantage. Professionals' intention to stay has major impact towards their organizations. It is because professionals as employees hired by the organization were actually the outward face of the organization and able to open up the new possibilities for the organization success due to their expanding skill and knowledge thus influenced the productivity, service and the profitability (Syahrulniza, 2015). Aware of this consequences, vast literatures pertaining to this issue were found and it was more appealing among professionals (Brannon, Zinn, Mor and Davis, 2002). Instead of depending on the traditional organizations effort to retain the professionals, one should look upon the individual reflection about themselves in making up their decision because professionals themselves as employees are self-driven in their job to fulfil their 
INTERNATIONAL JOURNAL OF ACADEMIC RESEARCH IN BUSINESS AND SOCIAL SCIENCES Vol. 8, No. 10, Oct. 2018, E-ISSN: 2222-6990 @ 2018 HRMARS

personal needs (Hall and Las, 2010). Individual reflection enables one to process and make meaning from the working experiences that they had. Through reflection, professional improves his or her perspectives, and allows them to re-appreciate the work that they do and grow from the experiences. Professionals learn and practice how to navigate their career based on personal values (Reitman and Schneer, 2008).

Malaysia has attempted to achieve the long term global competitiveness through transformation of manufacturing sectors (MITI, 2010), and for that various efforts has been taken along the way until Malaysia has finally been regarded as the main manufacturing hub in Asia Pacific (Global Manufacturing Index, 2015). This success initiates the sectors to be more rampant and become the major absorber of human workforce. Earle (2003) forecasted for the next fifteen years which is in 2018, the post for professionals will be arise to thirty-three percent meanwhile in the current year there are fifteen percent drop on professional employees supply. This will surely encouraged more competition between organizations to retain their professional employees because the professionals have more opportunities to job hopping due to the mushrooming organizations by local and foreign investors. The changing trend in industry needs organization to response towards the changes by bringing skills in order to keep ahead of the curve. The professionals are the key individuals with the critical knowledge and skill. Therefore, the action of retaining the professionals are considered worthwhile.

Professionals' retention in organizations can avoid detrimental effects to the manufacturing sectors. It can nullify the productivity losses, the costs of new replacement acquisition as well as impact on financial performance of the organization. Human capital is very much important for manufacturers because they are able to put them at risk. Dogan, Wong and Yap (2013) stated manufacturing is the engine of growth for Malaysia as it provides big number of employment. However, Lim (2015) argued that the manufacturing sector is experiencing high turnover employees especially among professionals. Nevertheless, the presence of new foreign entrants could enhance competition in the Malaysian manufacturing sector. For example, foreign entrants with superior performance will promote greater competition in the industry and force professionals to hop between the manufacturing according to the attractive offers. This study helps manufacturers to be more confident and capable to retain professionals in their organization.

Job satisfaction is important in any organization to secure the retention of their employees because it yield the result of less turnover problem. Although there are many concerns on job satisfaction among business practitioners and it has been studied for many years, the needs to study on job satisfaction still varies among different populations of employees (Yucel, 2012). Verhaest and Verhofstadt (2016) found that individuals with higher education background who is referred to as the professionals in this study, affects their perspectives on job satisfaction. Therefore, knowing that the effect of job satisfaction may varies in this population of study, job satisfaction is adopted to be tested as mediator between personal-related factors and intention to stay.

Hence this study aims to examine the influence of personal-related factors on intention to stay and the role of job satisfaction as mediator. This study extends the existing literatures of intention to stay, particularly in the aspect of personal-related factors on professionals' intention to stay. This study provides insights to HRD practitioners on the personal factors influencing professional intention to stay and these inputs could be used to design intervention programs. The paper is organized as 
follows: We begin by reviewing the definitions of intention to stay, presenting the empirical studies between personal-related factors and intention to stay. We then state our propositions, the methodological aspect of this study, followed by the research findings and discussion. Finally we discussed the implications for practice and future research.

\section{Defining Intention to Stay}

Intention to stay has its root from the widely conducted studies, i.e., turnover intention. Although intention to stay and intention to leave are known as the opposite side of the coin, it is essential to differentiate between the two (Cho, Johanson and Guchait, 2009). Hewitt (2004) defined intention to stay as the indicator of employees' commitment and willingness of the employees to remain employed by the current organization. Intention to stay may also referred as the propensity of employees to leave, the intention to leave or stay and it is the behavioural commitment and attachment (Halaby, 1986; Mueller, Iverson, and Price, 1999). Aslam and Safdar (2012), Eketu and Ogbu (2017) defined intention to stay as the intention of employees to have long term relationship with the current employer.

\section{Literature Review}

\section{Theorizing Professionals' Intention to Stay in Organization}

Intention to stay has its roots of explanation from the Social Exchange Theory. The theory explains on why individuals have relationship with others (Thibaut and Kelley, 1959). In 1964, Blau pointed the obligation towards others exist when individuals felt that they have received the benefits from the action taken. Obligation is the path to individual loyalty and thus channelling it through commitment and strong intention to stay with current employer (Mossholder, Settoon and Henagan, 2005; Mustafa, Ahmad, Uli, and Lis, 2010). The sense of obligation itself creates the positive psychological responses towards employees (Bunderson, 2001; Coyle- Shapiro and Kessler, 2000). When the professionals have the sense to repay back the organization due to the positive psychological response, this will avoid the feeling of self-withdrawal from organization. According to Thiruchelvi and Supriya (2009), among the emotional responses found at the workplace is job satisfaction, resulted from the positive feeling generated at the workplace. In this study, we include two identified personal-related factors (emotional intelligence, and self-efficacy) as contributors to professionals' job satisfaction and intention to stay. We posit that job satisfaction ignites the possibility of professional employees to remain in current organization (Spector, 1997).

Mobley's Model of turnover process (1979) explains the process of employees' decision making in either to stay or to leave the organization. There are ten stages in Mobley's Model of turnover process involving evaluation with current job (i.e. emotional intelligence and self- efficacy), determination of job satisfaction and planning process whether to stay or to quit. Based on the above, Figure 1 illustrates the proposed framework used in this study. 
INTERNATIONAL JOURNAL OF ACADEMIC RESEARCH IN BUSINESS AND SOCIAL SCIENCES Vol. 8, No. 10, Oct. 2018, E-ISSN: 2222-6990 @ 2018 HRMARS

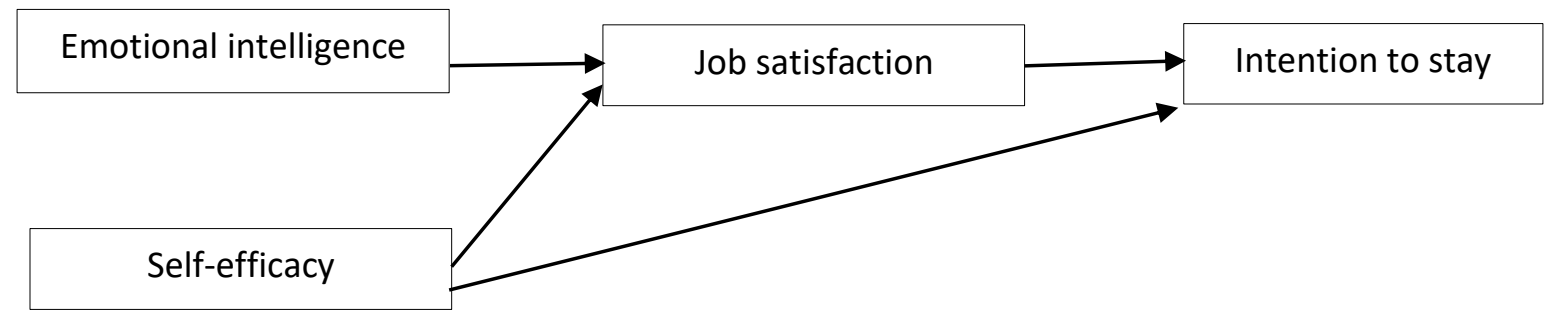

Figure 1: The emotional intelligence, self-efficacy, intention to stay and the mediating role of job satisfaction.

The Relationships between Personal factors, Job Satisfaction and Intention to Stay Job Satisfaction and Intention to Stay

In this study, job satisfaction acts as the mediator variable between personal factors and professionals' intention to stay. Job satisfaction is "a pleasurable emotional state resulting from the appraisal of one's job as achieving or facilitating the achievement of one's job values (Locke, 1969, pp. 316). It is a kind of evaluation made by employee towards his or her work content. It can also be regarded as an appraisal from employees about their job characteristics, work environment and emotional experiences found at the workplace (Thiruchelvi and Supriya, 2009). In this study, job satisfaction has been defined as emotional state of professionals towards his or her job, whether they like or not, based on their expectation and the actual reality of their job. Many research prove that the more satisfied the persons with their job, the more the persons will be likely to remain in their organization (Mitchell et al., 2001; Mobley, 1979; Bang, 2015). Yucel (2012) in his previous work also found the direct effect between job satisfactions towards intention to stay in organization. This finding enhanced the statement made by Meyer and Allen (1997) and Butler, Viot, Narrigon and Taylor (2005) whom indicated that job satisfaction results to commitment towards organization. It is also argued that job satisfaction could bring individual sense of staying with current organization instead of leaving (Bang, 2011; Costen and Salazar, 2011; Chen, Ployhart, Thomas, Anderson, and Bliese, 2011; Lopez, White and Carder, 2014). Zeytinoglu, Keser, Yilmaz and Ozsoy's (2010) and Chiang, Joon and Canter's (2005) studies also supported the significant role of job satisfaction as a mediator to employees' intention to stay in banking and hotel industries. Based on the above, we propose:

H1: Job satisfaction has significant relationship with professionals' intention to stay

H2-2: Job satisfaction mediates the relationship between emotional intelligence and professionals' intention to stay

H3-2: Job satisfaction mediates the relationship between self-efficacy and professionals' intention to stay 
INTERNATIONAL JOURNAL OF ACADEMIC RESEARCH IN BUSINESS AND SOCIAL SCIENCES Vol. 8, No. 10, Oct. 2018, E-ISSN: 2222-6990 @ 2018 HRMARS

\section{Emotional Intelligence and Intention to Stay}

Emotional intelligence is professionals' ability to recognize and regulate the emotion and in turn guide their thinking and action. According to Bar-On (2002), one can adapt in the workplace when possessing understanding, adjustment, know how to handle and express his or her emotions due to work pressure. It is believe that individual who can handle and adapt with the situation are able to avoid stress. Individual with high emotional intelligence enables one to astray the dysfunctional emotion and able to alleviate anger and frustration. Past research proved the positive relationship between emotional intelligence and intention to stay (Goleman, 2008). In 2007, Adeyemo and Afolabi found that individual who has low level of emotional intelligence tends to leave their current employer. This finding supported our study and revealed that employees with high level of emotional intelligence are much more inclined to leave their current organization because they are able to put themselves in a positive affective state.

Therefore, this study proposed:

H2-1: Emotional intelligence has significant relationship with professionals' intention to stay.

\section{Self-efficacy and Intention to Stay}

Self-efficacy is described as individuals' personality which significantly influences individuals' behaviour at the workplace (Barrick, Parks, and Mount, 2005; Judge and Bono, 2001). It can be referred to as individual's beliefs about their ability to execute tasks given successfully (Bandura, 1997). Wood and Bandura (1989) has found the significant relationship between self-efficacy and job satisfaction. Ability to control and deal with difficulties can help the professionals to execute their tasks successfully. Judge and Bono's (2001) work agreed on the role of self-efficacy to enhance the likelihood of someone enjoying in what they currently doing and gaining satisfaction. This is resulting from the individual's effectively dealing with the hardness and difficulties at work, and people with high self-efficacy is full of persistence to learning from the failure (Gist and Mitchell, 1992). Therefore, we propose:

H3-1: Self-efficacy has significant relationship with professionals' intention to stay

\section{Method}

\section{Sample and procedures}

We distributed the questionnaires to professional employees in Malaysia's manufacturing sector. The list of manufacturers were accessed from the Federation of Malaysian Manufacturers Directory 2015. Disproportionate cluster random sampling technique was employed to select the samples for this study. The human resource personnel for each selected manufacturing were contacted, and we negotiated through formal letters and phone calls to access the lists of professionals. A total of 500 respondents were asked to complete the questionnaires for about two to three weeks and the response rate was 91.4 percent with 457 questionnaires were collected and used for data analysis. 
INTERNATIONAL JOURNAL OF ACADEMIC RESEARCH IN BUSINESS AND SOCIAL SCIENCES

Vol. 8, No. 10, Oct. 2018, E-ISSN: 2222-6990 ㄷ 2018 HRMARS

\section{Measures}

The self-administered questionnaire were used. Before the actual data collection were made, pilot tests were conducted to ensure the validity and the reliability of the instrument used. The reported Cronbach's Alpha shows that all the construct have passed .70, which indicates the stability and consistency.

Intention to stay is defined as the commitment and willingness to remain employed with current employer in a long term basis. In this study, Intention to stay was measured using eleven items from Kyndt, Dochy, Michielsen and Moeyart's (2009) scale. A sample item is "If it were up to me, I will definitely be working for this company for the next five years".

Job satisfaction is defined as individual's emotional state towards his or her job. Job satisfaction was measured using seven items from Fernand and Awamleh (2006). Among the sample item is "I find that my opinions are respected at work".

Emotional intelligence is defined as professional employees' ability to recognize and regulate their emotion to lead one's thinking and action. Emotional intelligence was measured using measures from Wong and Law (2002) with eleven items. A sample item is "I can always calm down quickly when I am very angry".

Self-efficacy is professionals' judgement on their capabilities to execute tasks by superior. Selfefficacy was measured using measure from Schyns and Von Collani (2002) with eight items. A sample item includes "I am prepared to meet most of the demands in my job".

\section{Data Analyses}

Data were then analysed using SPSS Version 22 for the descriptive results (such as mean and standard deviation) and SEM-AMOS to determine the mediation effect of JS towards EI and ITS, and mediation effect of JS towards SE and ITS. The convergent validity refers to which measure of constructs shares the common variance. It can be tested through Average variance extract (AVE), Factor loading and Composite reliability (CR). The convergent validity of all constructs in this sudy were reported with the AVE higher than .5 and all factor loading are more than .5 which were all acceptable. Table 1 shows the result of AVE.

Table 1: The Average variance extract (AVE)

\begin{tabular}{cc}
\hline Latent construct & Average variance extract (AVE) \\
\hline Intention to stay & .621 \\
Job satisfaction & .604 \\
Emotional intelligence & .622 \\
Self-efficacy & .627 \\
\hline
\end{tabular}


Discriminant validity shows the relationship between the latent constructs and other constructs of similar nature. The correlation between constructs must be less than 0.9 or the AVE must be larger than any squared correlation among any pair of latent construct to not violate the discriminant validity. The results established the discriminant validity of this study. The values of correlation matrix are as illustrated in Table 2.

Table 2: Correlation matrix of all constructs

\begin{tabular}{lllll}
\hline Latent construct & $\begin{array}{l}\text { Intention to } \\
\text { stay }\end{array}$ & Job satisfaction & $\begin{array}{l}\text { Emotional } \\
\text { intelligence }\end{array}$ & $\begin{array}{l}\text { Self- } \\
\text { efficacy }\end{array}$ \\
\hline Intention to stay & 1 & & & \\
Job satisfaction & .860 & 1 & 1 & \\
Emotional intelligence & .649 & .666 & & 1 \\
Self-efficacy & .634 & .675 & .876 & \\
\hline
\end{tabular}

\section{Results and Findings}

Descriptive analysis

This study involved 457 respondents, with 83.8 percent of the respondents were males and 16.2 percent were females. All respondents were reported to have tertiary education for the professional post in their workplace. The summary of demographic profile of respondents is presented in Table 3. 
INTERNATIONAL JOURNAL OF ACADEMIC RESEARCH IN BUSINESS AND SOCIAL SCIENCES

Vol. 8, No. 10, Oct. 2018, E-ISSN: 2222-6990 @ 2018 HRMARS

Table 3: Demographic Profile of the Respondents

\begin{tabular}{|c|c|c|c|c|c|c|}
\hline Characteristics & Frequencies & (\%) & $M$ & $S D$ & Min & $\operatorname{Max}$ \\
\hline \multicolumn{7}{|l|}{ Age Category (years) } \\
\hline $12-34$ & 228 & 49.90 & & & & \\
\hline $35-55$ & 229 & 50.10 & & & & \\
\hline \multicolumn{7}{|l|}{ Sub-sectors } \\
\hline Palm oil & 152 & 33.30 & & & & \\
\hline Electrical and electronics & 155 & 33.90 & & & & \\
\hline Refined petroleum products & 150 & 32.80 & & & & \\
\hline \multicolumn{7}{|l|}{ Gender } \\
\hline Male & 383 & 83.80 & & & & \\
\hline Female & 74 & 16.20 & & & & \\
\hline \multicolumn{7}{|l|}{ Marital status } \\
\hline Single & 181 & 39.60 & & & & \\
\hline Married & 267 & 58.40 & & & & \\
\hline Divorced & 9 & 2.00 & & & & \\
\hline \multicolumn{7}{|l|}{ Highest education level } \\
\hline Bachelor degree & 375 & 82.10 & & & & \\
\hline Master degree & 77 & 16.80 & & & & \\
\hline PhD & 4 & 0.90 & & & & \\
\hline Other & 1 & 0.20 & & & & \\
\hline \multicolumn{7}{|l|}{ Current job position } \\
\hline Executive & 188 & 41.10 & & & & \\
\hline Officer & 206 & 45.10 & & & & \\
\hline Manager & 47 & 10.30 & & & & \\
\hline Others & 15 & 3.30 & & & & \\
\hline Tenure current job position & & & 5.66 & 2.26 & 2.00 & 15.00 \\
\hline $\begin{array}{l}\text { Total working years in current } \\
\text { organization }\end{array}$ & & & 6.87 & 2.84 & 1.00 & 16.00 \\
\hline Tenure of overall work experience & & & 10.89 & 4.91 & 2.00 & 35.00 \\
\hline \multicolumn{7}{|l|}{ Monthly income (RM) } \\
\hline RM 1,500 or less & 0 & 0 & & & & \\
\hline RM 1,501 - RM 2,500 & 34 & 7.40 & & & & \\
\hline RM 2,501 - RM 3,500 & 167 & 36.50 & & & & \\
\hline RM 3,501 - RM 4,000 & 153 & 33.50 & & & & \\
\hline RM 4,501 - RM 5,500 & 54 & 11.80 & & & & \\
\hline More than RM 5,500 & 49 & 10.70 & & & & \\
\hline
\end{tabular}


Total dependents/persons

0

$1-2$

3-4

5-6

More than 6
57

182

177

37

4
12.50

39.80

38.70

8.10

0.90

Table 4 presents the level of four variables in this study (intention to stay, job satisfaction, emotional intelligence, and self-efficacy). The level of intention to stay among professionals is reported as moderate. This shows that most professionals were at neutral bar in deciding their future whether or not they will stay for a longer time with their current employer. The result provides an alarm that majority of the professionals are not enthusiastic stayers. An enthusiastic stayers will want to stay and feel that they can stay (Lee, Hom, Eberly, and Li, 2017). If the result yields high level of intention to stay, means majority of the professionals are an enthusiastic stayers. However, the level of job satisfaction were reported as high, indicates that most of the professionals are satisfied with their jobs and surrounding factors that perceived as meeting expectations at their workplace. This result provides support that most of the organizations are successful at providing platform for professionals to share their ideas, recognizes the professionals, good pay structures, good relationship between superior and colleagues

Table 4: Level of intention to stay, job satisfaction, emotional intelligence, and self-efficacy

\begin{tabular}{|l|c|c|}
\hline \multicolumn{1}{|c|}{ Level } & M & SD \\
\hline Intention to stay & 3.39 & 0.55 \\
\hline Job satisfaction & 3.68 & 0.62 \\
\hline Emotional intelligence & 5.31 & 0.77 \\
\hline Self-efficacy & 5.45 & 0.76 \\
\hline
\end{tabular}

Note: Intention to stay and Job satisfaction (1.00-2.33 = low, 2.34-3.66 = moderate, 3.67-5.00 = high), Emotional intelligence and Self-efficacy (1.00-2.99 = low, 3.00-4.99 = moderate, 5.00-7.00 = high)

\section{Measurement Model}

The goodness of fit indices suggest a good fit of overall measurement model of this study $\left(\chi^{2}=\right.$ 539.613, $\chi^{2} / \mathrm{df}=2.006, \mathrm{GFI}=0.913, \mathrm{AGFI}=0.895, \mathrm{CFI}=0.968, \mathrm{IFI}=0.968, \mathrm{NFI}=0.938, \mathrm{TLI}=0.964$, RMSEA $=0.047)$. The gist of the overall measurement model are as shown in Table 5. 
INTERNATIONAL JOURNAL OF ACADEMIC RESEARCH IN BUSINESS AND SOCIAL SCIENCES Vol. 8, No. 10, Oct. 2018, E-ISSN: 2222-6990 @ 2018 HRMARS

Table 5: Goodness of fit indices of measurement model

\begin{tabular}{ccccccc}
\hline $\begin{array}{c}\text { Goodness of } \\
\text { fit index }\end{array}$ & CMIN $\left(\chi^{2}\right)$ & $\left(\chi^{2} / \mathbf{d f}\right)$ & CFI & IFI & TLI & RMSEA \\
\hline VALUE & $\begin{array}{c}539.613 \\
(P=0.000)\end{array}$ & 2.006 & .968 & .968 & .964 & 0.047 \\
\hline
\end{tabular}

\section{Testing the hypotheses}

To test the hypotheses developed for this study, the direct model and indirect model were used in order to examine the existence of mediating effects in structural model. The direct relationship between constructs were shown in Table 6.

Table 6: The regression weights in direct model

\begin{tabular}{lllllll}
\hline No & \multicolumn{1}{c}{$\begin{array}{c}\text { Hypothesized } \\
\text { relationship }\end{array}$} & $\begin{array}{c}\text { Beta } \\
\text { (Standardized) }\end{array}$ & $\begin{array}{c}\text { Beta (Un- } \\
\text { standardized) }\end{array}$ & S.E & C.R & p-value \\
\hline 1. & $\begin{array}{l}\text { Job satisfaction } \rightarrow \\
\text { Intention to stay }\end{array}$ & .896 & .948 & .071 & 13.346 & .000 \\
\hline 2. & $\begin{array}{l}\text { Emotional intelligence } \\
\text { Intention to stay }\end{array}$ & .332 & .266 & .084 & 3.156 & .002 \\
\hline 3. & $\begin{array}{l}\text { Self-efficacy } \rightarrow \\
\text { Intention to stay }\end{array}$ & .344 & .292 & .089 & 3.279 & .001 \\
\hline
\end{tabular}

Based on the results, job satisfaction has significant relationship with intention to stay $(\beta=.896, C . R$ $=13.346, p=.000)$. Thus, $\boldsymbol{H} \mathbf{1}$ is supported. Emotional intelligence is also reported to have significant relationship with intention to stay $(\beta=.332, C . R=3.156, p=.002)$, thus $\mathbf{H 2 - 1}$ is supported. The results also portrayed that self-efficacy has significant relationship with intention to stay $(\beta=.344, C . R$ $=3.279, \mathrm{p}=.001)$. Thus, $\mathbf{H 3 - 1}$ is supported.

The mediating role of job satisfaction towards relationship between emotional intelligence and selfefficacy to intention to stay is illustrated in Table 7. Using bootstrap, the determination of mediation effect of job satisfaction is based on zero (0) location in the confidence interval (Cl) (Hayes, 2009). If zero is located outside the lower and upper value of bias-corrected $95 \%$ percentile of $\mathrm{Cl}$, it means the mediation effect is significant. 
INTERNATIONAL JOURNAL OF ACADEMIC RESEARCH IN BUSINESS AND SOCIAL SCIENCES Vol. 8, No. 10, Oct. 2018, E-ISSN: 2222-6990 @ 2018 HRMARS

Table 7: The estimation coefficient for mediation model

\begin{tabular}{lccccc}
\hline & $\begin{array}{c}\text { Point } \\
\text { estimate }\end{array}$ & SIE & \multicolumn{2}{c}{$\begin{array}{c}\text { Bootstrapping } \\
\text { BC Percentile 95\% Cl }\end{array}$} & P \\
\cline { 3 - 5 } & & & Lower & Upper & \\
\hline Emotional intelligence & .195 & .235 & -.072 & .399 & .951 \\
\hline Self-efficacy & .350 & .400 & .252 & .561 & .329 \\
\hline
\end{tabular}

Based on the Table 7, it is found that job satisfaction is not a mediating factor for emotional intelligence towards intention to stay among professionals $(\beta=.195, \mathrm{Cl}=-.072, .399, \mathrm{p}=.951)$. the location of zero (0) is between the lower and upper value of $\mathrm{Cl}$. Thus, H2-2 is not supported. Job satisfaction is also found to mediate the relationship of self-efficacy and intention to stay among professionals $(\beta=.350, \mathrm{Cl}=-.252, .561, \mathrm{p}=.329)$. Zero $(0)$ is located between lower and upper value of $\mathrm{Cl}$. Hence, $\boldsymbol{H 3 - 2}$ is supported.

\section{Discussion}

Based on this study, the results indicate that job satisfaction influenced professionals' intention to stay. Thus, development of any necessary plan for professionals to attain satisfaction in working at their workplace need to be addressed carefully by the employer and give primary importance. Without taking serious action on which factors could contribute to the professionals' satisfaction, the organization success may go unheeded. Instead of focusing on what current employer has provided for the professionals, sometimes it is good for employer to get to know their professionals' expectations since one size does not fits all. When it is possible for the workplace factors to bring satisfaction for professionals, it is also possible for the professionals themselves to seek more meaningful event for their own job satisfaction. The mindset of these professionals can change over time, therefore it is vital for organization to remain alert to such changes.

The established relationship of job satisfaction as a mediator between self-efficacy and intention to stay signals the importance of this factors to be considered by the organizations in hiring professionals. Professionals with good self-efficacy tend to satisfy their career and thus decide to stay with employer for longer basis. The individual adjustment might be different between persons. Therefore, professionals themselves has to look into their own potential based on personality for self-development and also to prevent loss towards organization. While the results show that job satisfaction mediates self-efficacy and contrary result went to emotional intelligence. Contrary to the previous literatures, we took consideration of the study context which many of literatures found were conducted in other countries than Malaysia. Emotional intelligence itself is found to be a crucial part in managing individual's emotion and stress. Although it is challenging to predict the emotional intelligence of different individuals and how they react with stress and emotions during tight situation in the workplace, employers might try to counteract certain external pressures. For example, by organizing the motivation camp or class for stress management, professionals benefitting it by applying the correct ways to combat negativity. It is therefore, action taken by employers might influence the decision of professionals to stay. Previous scholars such as Ghoreishi, Zahirrodine, 
INTERNATIONAL JOURNAL OF ACADEMIC RESEARCH IN BUSINESS AND SOCIAL SCIENCES Vol. 8, No. 10, Oct. 2018, E-ISSN: 2222-6990 ㄷ 2018 HRMARS

Assarian, Moosavi and Mehrizi (2014) also found that stress management is not link to job satisfaction. Franek and Vecera (2008) also has voiced that the relationship between the personality traits and job satisfaction was less robust.

\section{Implications}

By integrating the Social Exchange Theory and Mobley's Model of Turnover, the study added supportive value to the existing bodies of literatures. The theoretical model suggested for this study provides some insight in explaining the interrelationships between the constructs. This link between theoretical perspective and action is something that benefit both the organization management and literature. We believe that our results also are able to provide insight in order for organization to plan or develop some new interventions in their strategic human capital planning. For example, through identification of personality trait made by recruiter, the organizations could have benefited by hiring the exact professional needed by them. Thus, this non-imitable assets were just fine to work well with the compatible position. As for personal development, the professionals also are aware with their personality trait in finding the ideal organization.

\section{Limitations and Future Research}

Despite the contributions of this study, it is not without any limitations. First, our data were collected through self-administered questionnaire which highly depends on the respondents' honesty in answering the questions. Therefore, there is a possibility of facing the common variance. Therefore, future research is suggested to gain the rich and details data through qualitative study. Beside that, there may also be other explanation on why professional stay in organization. Future researcher could test another trait factors since this study confined itself with only personal-related factors. The results of this study are only applicable to the professionals who works at the manufacturing sectors in Malaysia. Therefore, the findings may not be generalized to other groups of employees and other sectors. Future research can be done across countries with different cultures because cultural values are crucial factors influencing employees' norms in their working life (Chen and Tjosvold, 2008). Thus, it is suggested for future researcher to employ the different cultural contexts and to compare and contrast between different culture.

\section{Acknowledgement}

This study is funded by the Fundamental Research Grant Scheme of Universiti Putra Malaysia.

\section{Corresponding Author}

Roziah Mohd Rasdi. Head of Department, Department of Professional Development and Continuing Education Faculty of Educational Studies, Universiti Putra Malaysia, 43400 Serdang, Malaysia.

Email: roziah_m@upm.edu.my 
INTERNATIONAL JOURNAL OF ACADEMIC RESEARCH IN BUSINESS AND SOCIAL SCIENCES

Vol. 8, No. 10, Oct. 2018, E-ISSN: 2222-6990 @ 2018 HRMARS

\section{References}

Adeyemo, D. A., \& Afolabi, J. O. (2007). Influence of sexual harassment, occupational stress, emotional intelligence and job satisfaction on withdrawal cognition of female practitioners in Oyo state, Nigeria. Pakistan Journal of Social Sciences, 4(4), 639-646.

Aslam, M. S., \& Safdar, U. (2012). The influence of job burnout on intention to stay in the organization: mediating role of affective commitment. Journal of Basic and Applied Scientific Research, 2(4), 4016-4025.

Awamleh R, Fernandes C (2006). Impact of organizational justice in an expatriate work environment. Manage. Res. News, 29(11): 701- 712.

Bandura, A. (1997). Self-efficacy: The exercise of control. Macmillan.

Bang, H. (2011). Leader-member exchange in nonprofit sport organizations: The impact on job satisfaction and intention to stay from the perspectives of volunteer leaders and followers. Nonprofit Management and Leadership, 22(1), 85-105.

Bang, H. (2015). Volunteer age, job satisfaction, and intention to stay: A case of nonprofit sport organizations. Leadership \& Organization Development Journal, 36(2), 161-176.

Bar-On, R. (2002). EQ-i BarOn Emotional Quotient Inventory: A Measure of Emotional Intelligence: User's Manual. MHS.

Barrick, M. R., Parks, L., \& Mount, M. K. (2005). Self-monitoring as a moderator of the relationships between personality traits and performance. Personnel Psychology, 58(3), 745-767.

Blau, P. M. (1964). Exchange and power in social life. New York: Wiley.

Brannon, D., Zinn, J. S., Mor, V., \& Davis, J. (2002). An exploration of job, organizational, and environmental factors associated with high and low nursing assistant turnover. The Gerontologist, 42(2), 159-168.

Bunderson, J. S. (2001). How work ideologies shape the psychological contracts of professional employees: Doctors' responses to perceived breach. Journal of Organizational Behavior: The International Journal of Industrial, Occupational and Organizational Psychology and Behavior, 22(7), 717-741.

Butler, A., Viet, K., Narrigon, E., \& Taylor, E. (2005). Models of social support and work-school conflict. Society for Industrial and Organizational Psychology. Los Angeles.

Chen, G., \& Tjosvold, D. (2008). Organizational values and procedures as antecedents for goal interdependence and collaborative effectiveness. Asia Pacific Journal of Management, 25(1), 93-112.

Chen, G., Ployhart, R. E., Thomas, H. C., Anderson, N., \& Bliese, P. D. (2011). The power of momentum: A new model of dynamic relationships between job satisfaction change and turnover intentions. Academy of Management Journal, 54(1), 159-181.

Chiang, C. F., Back, K. J., \& Canter, D. D. (2005). The impact of employee training on job satisfaction and intention to stay in the hotel industry. Journal of Human Resources in Hospitality \& Tourism, 4(2), 99-118.

Cho, S., Johanson, M. M., \& Guchait, P. (2009). Employees' intent to leave: A comparison of determinants of intent to leave versus intent to stay. International Journal of Hospitality Management, 28(3), 374-381. 
INTERNATIONAL JOURNAL OF ACADEMIC RESEARCH IN BUSINESS AND SOCIAL SCIENCES

Vol. 8, No. 10, Oct. 2018, E-ISSN: 2222-6990 @ 2018 HRMARS

Costen, W. M., \& Salazar, J. (2011). The impact of training and development on employees' job satisfaction, loyalty, and intent to stay in the lodging industry. Journal of Human Resources in Hospitality \& Tourism, 10(3), 273-284.

Coyle-Shapiro, J., \& Kessler, I. (2000). Consequences of the psychological contract for the employment relationship: A large scale survey. Journal of management studies, 37(7), 903930.

Dogan, E., Wong, K. N., \& Yap, M. M. (2013). Turnover, ownership and productivity in Malaysian manufacturing. Journal of the Asia Pacific Economy, 18(1), 26-50.

Eketu, C. A., \& Ogbu, E. F. (2017). Human resource planning and organisational sustainability: A study of selected telecommunication firms in Rivers State. International Journal of Social Sciences and Management Research, 3(3), 37-46.

Franěk, M., \& Večeřa, J. (2008). Personal characteristics and job satisfaction.

Ghoreishi, F. S., Zahirrodine, A. R., Assarian, F., Moosavi, S. G. A., \& Mehrizi, M. Z. Z. (2014). Evaluation of emotional intelligence and job satisfaction in employees of kashan hospitals. Nursing and midwifery studies, 3(1).

Gist, M. E., \& Mitchell, T. R. (1992). Self-efficacy: A theoretical analysis of its determinants and malleability. Academy of Management review, 17(2), 183-211.

Goleman, D. (2008). Destructive emotions: A scientific dialogue with the Dalai Lama. Bantam.

Gubler, M., Arnold, J., \& Coombs, C. (2014). Reassessing the protean career concept: Empirical findings, conceptual components, and measurement. Journal of Organizational Behavior, 35(S1), S23-S40.

Halaby, C. N. (1986). Worker attachment and workplace authority. American Sociological Review, 634-649.

Hall, D. T., \& Las, H. M. (2010). Reintegrating job design and career theory: Creating not just good jobs but smart jobs. Journal of Organizational Behavior, 31(2-3), 448-462. http://dx.doi.org/10.1002/job.613

Hewitt Associates. (2004). Strategies for Cost Management of the HR Function. Timely Topics Survey Results.

Judge, T. A., \& Bono, J. E. (2001). Relationship of core self-evaluations traits-self-esteem, generalized self-efficacy, locus of control, and emotional stability-with job satisfaction and job performance: A meta-analysis. Journal of applied Psychology, 86(1), 80.

Kyndt, E., \& Dochy, F. M. M., \& Moeyart, B.(2009). Employee retention: Organisational and personal perspectives. Vocations and Learning, 2(3), 195-215.

Lee, T. W., Hom, P., Eberly, M., \& Li, J. J. (2017). Managing employee retention and turnover with 21st century ideas. Organizational Dynamics.

Lim, C. S. (2015). The Study on Factors Influencing Employee Turnover in E \& E Manufacturing Industry in Northern Malaysia (Doctoral dissertation, Universiti Sains Malaysia).

Locke, E. A. (1969). What is job satisfaction? Organizational behavior and human performance, 4(4), 309-336.

Lopez, C., White, D. L., \& Carder, P. C. (2014). Direct care worker's perceptions of job satisfaction following implementation of work-based learning. Journal of Applied Gerontology, 33(1), 97120. 
INTERNATIONAL JOURNAL OF ACADEMIC RESEARCH IN BUSINESS AND SOCIAL SCIENCES Vol. 8, No. 10, Oct. 2018, E-ISSN: 2222-6990 @ 2018 HRMARS

Meyer, J. P., Allen, N. J., \& Allen, N. J. (1997). Commitment in the workplace. Sage Publications.

Mitchell, T. R., Holtom, B. C., Lee, T. W., Sablynski, C. J., \& Erez, M. (2001). Why people stay: Using job embeddedness to predict voluntary turnover. Academy of management journal, 44(6), 1102-1121.

Mobley, W. H., Griffeth, R. W., Hand, H. H., \& Meglino, B. M. (1979). Review and conceptual analysis of the employee turnover process. Psychological Bulletin, 86(3), 493.

Mossholder, K. W., Settoon, R. P., \& Henagan, S. C. (2005). A relational perspective on turnover: Examining structural, attitudinal, and behavioral predictors. Academy of Management Journal, 48(4), 607-618.

Mueller, C. W., Finley, A., Iverson, R. D., \& Price, J. L. (1999). The effects of group racial composition on job satisfaction, organizational commitment, and career commitment: The case of teachers. Work and Occupations, 26(2), 187-219.

Mustapha, N., Ahmad, A., Uli, J., \& lis, K. (2010). Job characteristics as antecedents of intention to stay and mediating effects of work family facilitation and family satisfaction among single mothers in Malaysia. International Journal of Business and Social Science, 1(3).

Reitman, F., \& Schneer, J. A. (2008). Enabling the new careers of the 21st century. Organization Management Journal, 5(1), 17-28.

Schyns, B., \& Von Collani, G. (2002). A new occupational self-efficacy scale and its relation to personality constructs and organizational variables. European journal of work and organizational psychology, 11(2), 219-241.

Spector, P. E. (1997). Job satisfaction: Application, assessment, causes, and consequences (Vol. 3). Sage publications.

Syahrulniza, A. L. (2015). Factors related to intention to stay among gen Y in Malaysian manufacturing companies (Doctoral dissertation, Universiti Utara Malaysia).

Thibaut, J. W., \& Kelley, H. H. (1959). The social psychology of groups. New York: Wiley.

Thiruchelvi, A., \& Supriya, M. V. (2009). Emotional intelligence and job satisfaction. Asia Pacific Business Review, 5(2), 109-115.

Verhaest, D., \& Verhofstadt, E. (2016). Overeducation and job satisfaction: the role of job demands and control. International Journal of Manpower, 37(3), 456-473.

Wong, C. S., \& Law, K. S. (2002). The effects of leader and follower emotional intelligence on performance and attitude: An exploratory study. The leadership quarterly, 13(3), 243-274.

Wood, R., \& Bandura, A. (1989). Social cognitive theory of organizational management. Academy of management Review, 14(3), 361-384.

Yücel, i. (2012). Examining the relationships among job satisfaction, organizational commitment, and turnover intention: An empirical study. International Journal of Business and Management, 7(20), 44.

Zeytinoglu, I. U., Keser, A., Yılmaz, G., Inelmen, K., Özsoy, A., \& Uygur, D. (2012). Security in a sea of insecurity: Job security and intention to stay among service sector employees in Turkey. The International Journal of Human Resource Management, 23(13), 2809-2823. 